FIU Law Review

Spring 2017

\title{
Without Explanation: Judicial Restraint, Per Curiam Affirmances, and the Written Opinion Rule
}

Craig E. Leen

City Attorney of Coral Gables

Follow this and additional works at: https://ecollections.law.fiu.edu/lawreview

Part of the Courts Commons, and the State and Local Government Law Commons

Online ISSN: 2643-7759

\section{Recommended Citation}

Craig E. Leen, Without Explanation: Judicial Restraint, Per Curiam Affirmances, and the Written Opinion Rule, 12 FIU L. Rev. 309 (2017).

DOI: https://dx.doi.org/10.25148/lawrev.12.2.7

This Article is brought to you for free and open access by eCollections. It has been accepted for inclusion in FIU Law Review by an authorized editor of eCollections. For more information, please contact lisdavis@fiu.edu. 


\title{
Without Explanation: Judicial Restraint, Per CuRiam AFFIRMANCES, AND THE WRITTEN OPINION RULE
}

\author{
Craig E. Leen, Esq., BCS*
}

\section{INTRODUCTION}

Affirmed. Most decisions in Florida's intermediate appellate courts are decided by this one word, without further explanation. ${ }^{1}$ A per curiam affirmance ("PCA") effectively ends the case-as a PCA cannot be the basis for Florida Supreme Court review-and can be profoundly dissatisfying, as you may imagine, for the non-prevailing party and the attorney who must explain to that client why the court provided no explanation. In addition, although a party presumably prefers to prevail in a given case, a PCA provides no guidance for future cases, and thus may cause harm to prevailing parties, and particularly governmental parties, as they may have to confront the identical legal issues again without any guidance from the court or its PCA (and therefore may have to bear unnecessary risks and relitigate the same issues again).

For a period of approximately one year, I served as the Chair of the Ad Hoc Subcommittee on Per Curiam Affirmances for the Florida Appellate Court Rules Committee ("Subcommittee"). ${ }^{2}$ The Subcommittee was

\footnotetext{
* Craig E. Leen is the City Attorney of Coral Gables and is Board Certified by the Florida Bar in City, County, and Local Government Law. Mr. Leen is on the adjunct faculties of the Florida International University College of Law and the University of Miami School of Law. Prior to serving as City Attorney, Mr. Leen was an Assistant County Attorney for Miami-Dade County, where he was Chief of the Appeals Section for four years and Chief of the Federal Litigation section for one year. Prior to his government service, Mr. Leen worked as an associate at several international law firms and also served as a federal law clerk to the Honorable Robert E. Keeton, United States District Judge, District of Massachusetts. Mr. Leen presently serves on the Florida Rules of Judicial Administration Committee, including as Parliamentarian, on the Executive Council of the City, County, and Local Government Law Section of the Florida Bar, and as a member of the Ad Hoc Committee on Rules and Procedures (Local Rules Committee) for the Southern District of Florida. Mr. Leen previously served for six years on the Florida Appellate Rules Committee, including as Vice Chair.

Mr. Leen would like to give special thanks to his former intern and research assistant Patricia Yeatts, a student at St. Thomas University School of Law, who provided invaluable assistance to him in the preparation of this article.
}

1 See Ezequiel Lugo, The Conflict of PCA: When an Affirmative Without Opinion Conflicts with a Written Opinion, FLA. BAR J., April 2011, at 46, https://www.floridabar.org/DIVCOM/JN/JNJournal0 1.nsf/Articles/FF261723E3328AB385257863004BD234 (citing to COMMITTEE ON PER CURIAM AFFiRmed Decisions, Judicial MANAGEMENT COUNCIL, FinAl REPORT AND RECOMMENDATIONS 25 (2000), https://www.flcourts.org/core/fileparse.php/260/urlt/pca-report.pdf; OFFICE OF THE STATE COURTS ADMINISTRATOR, FloridA District COURTS OF APPEAL: A DESCRIPTIVE REVIEW 33 (2006)).

2 Agenda, SubcommitTeE ON PER CURIUM AFFirmances, Florida APPELlate COURT Rules COMMITTEE 357-82 (June 26, 2015), http://www.floridabar.org/cmdocs/cm205.nsf//cmdocs/cm205.nsf/ 
composed of judges and appellate attorneys dedicated to addressing PCAs and determining what to do about them. The Subcommittee debated both the positive and negative attributes of PCAs at length, even debating whether to abolish them. Ultimately, the Subcommittee unanimously recommended, and the full Committee unanimously approved, an expansion of a rule allowing a party to seek a written opinion following receipt of a PCA. ${ }^{3}$ I was proud to be part of this effort and am hopeful that it will address a number of the concerns raised about PCAs. ${ }^{4}$

The purpose of this article is to move away from the practical experience of the Subcommittee, which addressed a specific issue (the need to be able to ask, at times, for a written explanation following a PCA), to conduct a more scholarly evaluation of PCAs under the doctrine of judicial restraint, and to compare Florida's reliance on PCAs to what occurs in other states and the federal government. This article also analyzes PCAs under the doctrines of separation of powers, checks and balances, and judicial restraint, as well as other pragmatic considerations both for and against PCAs. This analysis eventually concludes with the recommendation that Florida move away from PCAs, either eliminating them in all instances or, if that is not practicable, only allowing them to be issued in frivolous appeals or appeals that are controlled by a clearly applicable binding precedent (which would then be cited), and ensuring that the judiciary has adequate resources to prepare explanations, even if brief, in most appellate decisions. $^{5}$

Consistent with this conclusion, I have also submitted a proposed constitutional amendment to the Constitution Revision Commission, an appointed body that is convened once every 20 years to propose revisions to the Constitution to the voters, ${ }^{6}$ which would require that all appellate decisions include an explanation of the basis for the decision. The explanation could be short (a citation to a case) or long (a comprehensive opinion) but either way the issues of PCAs would be fully addressed.

/c5aca7f8c251a58d85257236004a107f/8cd3dcfb6caeaf3485257de20074ab0a/\$FILE/ACRC\%20Agenda \%2006\%2026\%2015.002.pdf/ACRC\%20Agenda\%2006\%2026\%2015.pdf.

3 Id. at 23-26.

4 The propose rule has been submitted by the Florida Bar Board of Governors and Appellate Court Rules Committee to the Florida Supreme Court as Case No. SC 17-152.

5 This article does not directly address appellate court orders denying or dismissing a petition for extraordinary writ without explanation, which is similar to a PCA. In situations where the petition involves purely discretionary review, such as where second-tier certiorari is sought or where a pretrial discovery order is contested, there is less need for an opinion as the Court can simply decline review without commenting on the merits. In contrast, where an appeal as of right is taken through the vehicle of a petition for writ of certiorari under Florida Rule of Civil Procedure 9.100(c)(2), such as for zoning matters before local governments, the appellate court should provide an explanation to provide needed guidance to the local governments.

6 Art. XI, § 2, Fla. Const. 
Finally, to the extent there is no elimination or restriction of PCAs, either by rule or constitutional amendment, the article also analyzes the expanded written opinion rule that is before the Supreme Court. The expansion of the written opinion rule recognizes the importance of the judiciary's role in interpreting the law and providing an explanation and guidance to the other branches, including local governments, as to why a certain decision was reached.

\section{The Prevalence and Impact of Per Curiam Affirmances in Florida}

\section{a. The Prevalence of PCAs}

The PCA is the most common decision in the District Courts of Appeal of Florida. ${ }^{7}$ This has been true for the past two decades and continues to be true today. As part of a comprehensive report on PCAs, the Judicial Management Council ("JMC") accumulated extensive statistics on PCAs from 1983 through 1998. In 1983, the percentage of PCAs was 47\% of all decisions; in 1991, the percentage was 53\%; and in 1998, it was $61 \%$. From 1983 to 1998 , the amount of PCAs increased by $92.7 \%$ while the amount of total opinions only increased by $50.5 \%{ }^{8}$

From July 1998, through June 1999, the JMC did a comprehensive review of all PCAs issued by the District Courts of Appeal of Florida ("DCA" or "District Court"), which showed that $62.5 \%$ of all decisions that year were by PCA. The percentages were $68.7 \%$ for the First DCA, 73.2\% for the Second DCA, $51.9 \%$ for the Third DCA, 55.8\% for the Fourth DCA, and $58.4 \%$ for the Fifth DCA. ${ }^{9}$ Notably, the percentages ranged statewide from $69.2 \%$ for criminal matters, to $65.7 \%$ for administrative matters, to $45.7 \%$ for civil matters. ${ }^{10}$

As further discussed below, the JMC determined that the principle way to address the proliferation of PCAs was to allow a party to petition for a written opinion following a PCA. ${ }^{11}$ A rule of appellate procedure was developed to allow for a written opinion to be sought as part of a motion for rehearing following a PCA. ${ }^{12}$ This was the only structural recommendation made by the JMC to address PCAs.

7 Lugo, supra note 1, at 46 ("The affirmance without opinion, better known to appellate practitioners as a PCA, is by far the most prevalent appellate disposition in our district courts of appeal.").

8 See Committee on Per Curiam AfFirmed Decisions, supra note 1, at 23.

$9 \quad I d$. at 26.

10 Id.

11 Id. at 30-31.

12 Fla. R. App. P. 9.330(a). 
In 2015, the Subcommittee took another look at PCAs, concerned by their prevalence, and wanting to see if the written opinion rule had been effective in addressing PCAs. In addition to substantial anecdotal evidence documented in the minutes, the Subcommittee decided to look at one DCA to determine the frequency of PCAs. The Clerk's Office from the Fifth DCA was quite helpful in obtaining these statistics, which showed that PCAs without any citation comprised $75 \%$ of all decisions in $2011,65 \%$ in 2012, and $79 \%$ in $2013 .{ }^{13}$ When including citation PCAs (i.e., a PCA with a citation to a case), the prevalence went to $79 \%$ in $2011,78 \%$ in 2012 , and $81 \%$ in $2013 .^{14}$

In addition, a review of all opinions issued for the six-month period from February 2016 through July 2016 provides further evidence that PCAs constitute a supermajority of all DCA decisions in Florida. ${ }^{15}$ The average percentage of PCAs for all five DCAs combined during this time was $74.85 \%$, comprised of $75.71 \%$ for the First DCA, $84.64 \%$ for the Second DCA, $67.03 \%$ for the Third DCA, $71.74 \%$ for the Fourth DCA, and $77.78 \%$ for the Fifth DCA. ${ }^{16}$

The primary purpose of this article is not to determine to a precise number the amount of PCAs, or to draw any conclusions merely from the percentage. This information being provided is merely intended to show that PCAs are common, that the most likely outcome of an appeal to the District Courts is a PCA, and that they continue to be worth evaluating, such as by the Subcommittee and this article.

\section{b. The Impact of PCAs in Florida}

The principle legal implications of a PCA are twofold. First, a PCA cannot be the basis for conflict jurisdiction to the Florida Supreme Court. ${ }^{17}$

13 Agenda, Subcommittee on Per Curium AfFirmances, Florida Appellate Court RULES COMMITTEE 239 (Jan. 23, 2015), https://www.floridabar.org/cmdocs/cm205.nsf/c5aca7f8c251a5 8d85257236004a107f/8cd3dcfb6caeaf3485257de20074ab0a/\$FILE/ACRC\%20Agenda\%20Packet\%200 $1 \% 2023 \% 2015$.pdf.

14 Id.

15 The research was conducted by my research assistant under my supervision, involving review of the decisions issued by each of the five District Courts of Appeal during that time period. These decisions are publicly available on their websites. For example, the First District website allows decisions to be looked up based on whether or not the decisions are written opinions or per curiam affirmances, which is similar to the websites for the other District Courts. See, e.g., Opinions, FLORIDA FIRST DISTRICT COURT OF APPEAL, http://www.1dca.org/opinions/opinions_default.html (last visited Mar. 28, 2017).

16 See infra Table 2, Table 3 (indicating percentages of PCAs for six months in 2016).

17 See Jenkins v. State, 385 So. 2d 1356, 1359 (Fla. 1980) (determining that the Florida Supreme Court lacks jurisdiction to consider a per curiam affirmance, notwithstanding the inclusion of a dissent or concurrence). 
Second, PCAs cannot be cited as precedent or authority, except to demonstrate res judicata, and thereby cannot be used to resolve a recurring legal issue. ${ }^{18}$

The legal authority regarding PCAs and the jurisdiction of the Florida Supreme Court is quite extensive, and even resulted in an amendment to the Florida Constitution. ${ }^{19}$ This amendment limited conflict jurisdiction of the Florida Supreme Court to decisions where there was express and direct conflict between decisions of the District Courts of Appeal. ${ }^{20}$ Because a PCA provides no analysis, it has been determined that a PCA can never directly and expressly conflict with another decision. ${ }^{21}$

The prohibition on any potential conflict jurisdiction is slightly eased for PCAs that contain a citation to another case. ${ }^{22}$ In such circumstances, if the case that is cited is being reviewed by the Supreme Court, then the Supreme Court would have "tag" jurisdiction over the PCA until the case that is cited is fully reviewed. ${ }^{23}$ If the case being cited is reversed or vacated, the Florida Supreme Court could also act on the case where "tag" jurisdiction is present, presumably remanding the matter back to the District Court to reconsider in light of the Supreme Court's action. ${ }^{24}$

As a PCA is the most likely outcome of any appeal that is taken, an appellate practitioner must also address the professional and ethical obligations that come with filing an appeal. The practitioner must advise the

18 See State v. Swartz, 734 So. 2d 448, 448-49 (Fla. 1st DCA 1999) (“As has been stated countless times before, a per curiam affirmance decision without written opinion has no precedential value and should not be relied on for anything other than res judicata.") (citation omitted); see also Dep't of Legal Affairs v. District Court of Appeal, 5th District, 434 So. 2d 310 (Fla. 1983) ("The issue is whether a per curiam appellate court decision with no written opinion has any precedential value. We hold that it does not.").

19 Art. V, § 3(b)(3), Fla. Const. (further amended 1998).

20 In response to requests by the Supreme Court of Florida to decrease its workload, the Florida Constitution was amended in 1980 to specify that the Supreme Court's "conflict jurisdiction" was restricted to those situations in which a District Court's decision "expressly and directly conflicts with a decision of another district court of appeal or of the supreme court on the same question of law." See Lugo, supra note 1.

21 District COURT OF APPEAL WORKLOAD AND JURISDiCTION ASSESSMENT COMMitTEE, REPORT AND RECOMMENDATIONS 11, 20, 32 (2006). Although the Supreme Court has jurisdiction to consider cases that expressly and directly conflict with cases from another district court, the Florida Constitution does not permit the Supreme Court to review PCAs. R.J. Reynolds Tobacco Co. v. Kenyon, 882 So. 2d 986, 988-90 (Fla. 2004); Jenkins, 385 So. 2d at 1359.

22 Wells v. State, 132 So. 3d 1110, 1113-14 (Fla. 2014) (determining no jurisdiction over per curiam dismissal with a citation to a case that is not pending in and has not been quashed or reversed by the Florida Supreme Court).

23 Perkins v. State, 845 So. 2d 273, 274 (Fla. 2d DCA 2003) ("The supreme court generally does not have jurisdiction to review decisions issued without opinions. But it may review a 'citation PCA' if the citation is to a decision that either is pending review in or has been reversed by the supreme court.") (citation omitted).

$24 I d$. 
client that an appeal to the District Court is statistically unlikely to be successful and that any further appeal, such as to the Florida Supreme Court, may not be possible because of the prevalence of PCAs. In my experience, this is likely to result in parties being often unwilling to proceed with potentially meritorious cases and appeals, as the client must be advised, no matter the strength of the potential arguments, that if a trial or dispositive motion is lost at the trial court level, a PCA is statistically the most likely outcome on appeal.

In addition, for local governments raising sovereign immunity ${ }^{25}$ or similar defenses that may recur, there is the possibility that a PCA will be issued, awarding substantial damages to the plaintiff, while giving no guidance for future cases. For example, if a governmental entity asserts sovereign immunity as to suits regarding a particular governmental policy, and the lower tribunal rules on the defense by denying a dispositive motion without explanation, it is possible that an eventual PCA would result in the governmental entity never receiving an explanation as to why the various judges at both the trial court and appellate levels reviewing the matter felt that sovereign immunity did not apply. More importantly, however, because a PCA or a denial of a motion does not set binding precedent, it is possible that the local government may face the same issue again in the future and still be uncertain whether sovereign immunity or another defense applies. As further indicated below, the written opinion rule is intended to address this issue.

\section{c. Report by the Judicial Management Council's Committee on Per Curiam Affirmed Decisions}

In May 2000, the Judicial Management Council's Committee on Per Curiam Affirmed Decisions issued a report and recommendation on PCAs, in which the majority opinion largely supported them as a mechanism for resolving cases, albeit with dissenting opinions. ${ }^{26}$ The Committee also recommended a procedural rule allowing a party to seek a written opinion following receipt of a PCA on the sole grounds that an opinion would provide a basis for Florida Supreme Court review (i.e., that an opinion

25 Sovereign immunity can be raised by local governments and applies as a matter of law to bar suits where sovereign immunity has not been waived, such as for suits contesting planning level decisions and functions of the government. See generally Trianon Park Condo. Ass'n v. City of Hialeah, 468 So. 2d 912 (Fla. 1985). The immunity is so consequential that pre-trial orders determining that sovereign immunity does not apply are now subject to interlocutory review as non-final orders. See Fla. R. App. P. 9.130(a)(3)(C)(xi). It would therefore be counterintuitive that an appeal addressing sovereign immunity would be decided by a per curiam affirmance. Nevertheless, this possibility is one reason why I recommended the proposed written opinion rule discussed later in this article.

26 See COMmitTeE On Per CURIAM AFFiRmed DeCisions, supra note 1. 
would demonstrate conflict between the DCA issuing the PCA and another DCA). ${ }^{27}$

\section{d. Ad Hoc Subcommittee on Per Curiam Affirmances}

Fifteen years later the Appellate Court Rules Committee took a second look at PCAs through its Ad Hoc Subcommittee on Per Curiam Affirmances. ${ }^{28}$ The Subcommittee addressed a concern that PCAs were still frequently used, and that motions for written opinion were rarely granted. ${ }^{29}$ The Subcommittee considered whether to recommend a procedural rule eliminating PCAs, as well as alternate remedies to address some of the concerns raised by PCAs. ${ }^{30}$ This led to a proposed rule amendment to make it easier to seek a written opinion after receiving a PCA, which included expanding the grounds upon which a written opinion could be sought. ${ }^{31}$ For example, a local government could seek guidance as to why it lost a particular matter if the issue were recurring and the local government would have to act on similar issues in the future, even if the written opinion would not be a basis for Supreme Court review. ${ }^{32}$ The proposed rule change was approved by the Florida Appellate Court Rules Committee, and is in the process of being reviewed by the Florida Supreme Court in Case No. SC17$152 .^{33}$

As mentioned, I served as the Chair of the Ad Hoc Subcommittee on Per Curiam Affirmances, and also serve as City Attorney for the City of Coral Gables. These roles allow me to provide insights into the arguments for and against PCAs made during the subcommittee and committee meetings in the Florida Appellate Court Rules Committee, as well as the importance of judicial decisions as part of our system of checks and balances, particularly to government entities tasked with applying and enforcing the law, such as cities, counties, and other local governments.

27 Id. at 30-33.

28 See Minutes, ApPellate Court Rules CommitTeE 21-26 (June 26, 2015), https://www.flo ridabar.org/cmdocs/cm205.nsf/c5aca7f8c251a58d85257236004a107f/7368d9fbd6aa2a2b85257e3f0060e adf/\$FILE/ACRC\%20Minutes\%2006\%2026\%2015.002.pdf/ACRC\%20Minutes\%2006\%2026\%2015.pd f; Minutes, APPEllate Court Rules COMMitTEE 27-30 (Jan. 23, 2015), https://www.floridabar.org/c mdocs/cm205.nsf/c5aca7f8c251a58d85257236004a107f/7368d9fbd6aa2a2b85257e3f0060eadf/\$FILE/A CRC\%20Minutes\%2001\%2023\%2015\%20Updated\%2002\%2023\%2015.pdf.

29 See SubCOMmittee ON Per CURIUM AfFirmanCES (June 26, 2015), supra note 2, at 357-82.

$30 \quad I d$. at $358-60$.

31 Id. at $358-67$.

32 See id.

33 See Appellate Court Rules Committee, Three-Year CyCle Report 11-12 (2017), https://www.floridabar.org/TFB/TFBResources.nsf/Attachments/79DE168AF127C35085257FC6004C2 607/\$FILE/Appellate\%20Court\%20Rules\%20News\%20Chart.pdf?OpenElement. 


\section{The Legal Basis for and Against Per Curiam Affirmances a. For PCAs}

\section{i. Presumption of Validity}

The validity of the PCA is based squarely on the presumption of correctness afforded to all judgments and the historical concept of assignment of error. ${ }^{34}$ In other words, a judgment of a court of competent jurisdiction is considered to be valid and enforceable unless successfully challenged through an appropriate procedure..$^{35}$ The party that prevails in the underlying case in the lower tribunal need not seek to confirm that judgment with an appellate court. In contrast, in order to contest a judgment, the non-prevailing party must typically file a timely notice of appeal or timely petition for extraordinary writ and must identify the grounds for the challenge in either the brief (appeals) or the petition (writs). ${ }^{36}$

Based on this theory, since the underlying judgment is presumed correct and valid, the appellate court need not provide an explanation as to why the judgment is being affirmed, as the judgment is already presumed correct. The appellate court is essentially relying completely on the judgment of the lower tribunal. Nevertheless, this is not equivalent to adopting the lower tribunal's analysis or opinion, as that itself would be an explanation that could then be published and be binding (the appellate court would be issuing the lower tribunal's decision as its own decision). Indeed, it is a well-accepted principle that the appellate court may affirm a judgment for any reason supported by the record (referred to as the tipsy coachman doctrine). ${ }^{37}$ The PCA leaves it a mystery as to whether the appellate court is adopting the lower tribunal's analysis, agreeing with the arguments in the appellant's brief, or simply affirming the judgment for another reason.

34 See, e.g., Phipps v. Sheffman, 211 So. 2d 598, 599 (Fla. 3d DCA 1968) ("Nevertheless, the judgment appealed having been a final judgment, a presumption of correctness remains present and the appellants have the burden of showing error.").

35 Id.

36 Id. at 146.

37 See Vandergriff v. Vandergriff, 456 So. 2d 464, 466 (Fla. 1984) (recognizing "the wellestablished rule that trial court decisions are presumptively valid and should be affirmed, if correct, regardless of whether the reasons advanced are erroneous"); see also Fla. R. App. P. 9.210(b)(5) (requiring "[a]rgument with regard to each issue, with citation to appropriate authorities, and including the applicable appellate standard of review" for appellate briefs); Fla. R. App. P. 9.100(g) (requiring petition for extraordinary writ to include "(1) the basis for invoking the jurisdiction of the court; (2) the facts on which the petitioner relies; (3) the nature of the relief sought; and (4) argument in support of the petition and appropriate citations of authority"). 
This analysis does not apply, however, in the case of a reversal or vacation of the underlying judgment. In those cases, the appellate court cannot rely on the presumption of correctness and instead must provide reasons for its actions. The law clearly establishes that it would be error for an appellate court to reverse the decision of a lower tribunal without providing an explanation. ${ }^{38}$ Such a rule makes sense both to overcome the presumption of correctness and to ensure that the lower tribunal knows how to apply the law when the matter is remanded.

For example, as a City Attorney, I serve as counsel and parliamentarian for many quasi-judicial matters before the City Commission. In reviewing the decision of the Commission in a quasijudicial matter, the Circuit Court reviews the following three factors to determine whether they are present: (1) whether the decision was supported by competent, substantial evidence in the record; (2) whether there was a departure from the essential requirements of law; and (3) whether due process was observed. ${ }^{39}$ If the court could simply quash the decision of the Commission and remand without explanation, the Commission would not be advised as to what it should change from the prior hearing in order to be affirmed in the future. Indeed, there would be no guidance whatsoever.

Case law is very clear that per curiam reversals ("PCRs") are not permitted. The fundamental question then is whether PCAs are distinguishable, or whether they should be treated the same as PCRs. Although the presumption of correctness provides one ground of possible distinction between PCAs and PCRs, I will explain below how they are ultimately not distinguishable.

\section{ii. Separation of Powers}

A second justification provided for PCAs is the separation of powers doctrine; the concept being that courts are vested with the judicial power and should be able to determine when and to what extent to exercise that power. Any time a PCA is issued, the appellate court is essentially electing to not interpret the law in that area. ${ }^{40}$ This allows the other branches to still

38 Miami-Dade County v. Torbert, 39 So. 3d 482, 483 (Fla. 3d DCA 2010) (holding that circuit court could not reverse the lower tribunal without explanation, as that would amount to a per curiam reversal, which is impermissible); State Dep't of Highway Safety and Motor Vehicles v. Trauth, 937 So. 2d 758, 759-60 (Fla. 3d DCA 2006) (prohibiting action that amounts to a per curiam reversal of lower tribunal).

39 Haines City Community Development v. Heggs, 658 So. 2d 523, 530 (Fla. 1995).

40 See Newmons v. Lake Worth Drainage District, 87 So. 2d 49, 50-51 (Fla. 1956)

("Traditionally it may be pointed out that a 'per curiam' is the opinion of the court in which the judges are all of one mind and the question involved is so clear that it is not considered necessary to elaborate it by an extended discussion. Such an opinion carries no less weight because of the nomenclature that 
have a degree of leeway in how to enforce or apply the law, where they are not limited by a recently issued binding precedent.

A potentially stronger argument can be made that the use of PCAs undermines separation of powers as well. This is further discussed below when analyzing the doctrine of judicial restraint. In short, the PCA is an expression of will (i.e., an outcome) and does not contain any analysis connecting the decision to a statute or case demonstrating the exercise of legal reasoning. The democratic branches-legislative and executive-may take actions to accomplish the general will as a matter of policy and are beholden to the electorate in doing so. In contrast, the judiciary, as a counter-majoritarian institution, cannot rely on the vote or the general will to support any particular outcome; instead, such outcome's legitimacy is based on the fact it was reached through legal reasoning and the rule of law. Moreover, a PCA cannot serve as a check and balance on the other branches as it can provide no guidance as to the reasons the judiciary has reached this result.

\section{iii. Prudential Reasons: Resources}

A third justification provided for PCAs is the scarcity of judicial resources. The broad concern is that courts would have to devote significant time to drafting opinions in hundreds, or even thousands, of cases statewide to make a significant dent in the amount of PCAs issued each year. This would require greater reliance by judges on their law clerks and would divert time from opinion writing in the most important cases.

This concern is mitigated by the principle that a written opinion need only a sentence or two, or, perhaps, merely a citation, in order to provide sufficient reasoning for it to no longer be a PCA. Indeed, staff attorneys or clerks could easily prepare these short opinions for the panel to approve.

\section{b. Against PCAs}

\section{i. Federalist Papers}

The Framers established three coequal branches comprising the federal government: the legislative, executive, and judicial. The legislative and executive branches were democratically elected and were thereby vested with the authority to act through the exercise of their will, and thereby seek to reflect the general will as discussed by Rousseau. ${ }^{41}$ The judicial branch, in contrast, is not intended to exercise will, such as through policy choices,

41 See generally JEAN-JACQUES RousseAu, A DisCourSe On POLITICAL ECONOMY (1755). 
but should instead limit its inquiry to law and judgment. Indeed, the basis for the judicial power, which is referenced in Article V, Section 1 of the Florida Constitution, is found in Federalist Number 78, written by Alexander Hamilton as Publius, which states as follows:

It can be of no weight to say that the courts, on the pretense of a repugnancy, may substitute their own pleasure to the constitutional intentions of the legislature. This might as well happen in the case of two contradictory statutes; or it might as well happen in every adjudication upon any single statute. The courts must declare the sense of the law; and if they should be disposed to exercise WILL instead of JUDGMENT, the consequence would equally be the substitution of their pleasure to that of the legislative body. The observation, if it proves anything, would prove that there ought to be no judges distinct from that body. ${ }^{42}$

One significant concern with a PCA is that it is the quintessential outcome determinative decision or, in other words, an exercise of will. That is not to say that the District Court is acting in an outcome determinative manner; indeed, I would assume it is quite the contrary, and that the District Court does have sound reasons for its decision. This does not refute the fact, however, that a PCA only states the outcome, i.e. "Affirmed," without any analysis whatsoever as to why the lower tribunal's decision is being upheld. This concern can be compounded where the lower tribunal's decision does not contain any analysis either, such as where a motion for summary judgment is denied without explanation and is later affirmed by a PCA. In other words, the state court system as presently operating could decide a contentious legal issue at both the trial court and appellate court levels without providing any legal analysis at either level as to why the decision was reached. It is easy to imagine a losing party, particularly a private citizen who has made a significant investment of time and resources in hiring an attorney, becoming frustrated and even disillusioned with the legal system in such circumstances.

\section{ii. Judicial Restraint}

Based on Federalist Number 78, the principle of judicial restraint is served where an explanation is provided with every opinion pointing to the established legal authority supporting the decision. This is how the judiciary "declares the sense of the law,"

42 The FEDERALIST No. 78 (Alexander Hamilton).

43 Id. 
will. The concern with the PCA is that it is completely outcome determinative to the public, as it merely states the outcome with no explanation. It is the quintessential statement of judicial "will," which is the concern of Federalist Number 78, as well as any adherent to the principle of judicial restraint.

The benefit of reasoned analysis is that it demonstrates the legal basis for the decision, explaining to the parties and the public at large how the decision was based on recognized legal principles such as the doctrine of stare decisis, or on canons of construction, or even because the error raised was harmless under the law. Such explanations allow the losing party to accept the decision as an act of judgment instead of mere will, allowing both parties and non-parties to learn from the decision how to act in the future.

Once again, it is too easy for a party who receives a PCA, particularly after having paid the filing fee and hired an attorney who wrote a persuasive brief at some expense, to become skeptical of a judicial system that responds with a PCA and no explanation.

\section{iii. Florida Constitution}

As mentioned, the Florida Constitution vests the "judicial power" in the court system. ${ }^{44}$ This is similar to the reference in the United States Constitution to the vesting of the "judicial power" in Article III courts. ${ }^{45}$ The "judicial power" is typically defined to include interpreting and applying existing law to cases, and having the power of judicial review of statutes and executive actions. Such application of judicial power would presumably include an explanation of the existing law being interpreted or applied, as well as why a specific outcome was reached.

The Florida Constitution proceeds to explain the jurisdiction of the various courts that are referenced, including the Florida Supreme Court, which

[m] ay review any decision of a district court of appeal that expressly declares valid a state statute, or that expressly construes a provision of the state or federal constitution, or that expressly affects a class of constitutional or state officers, or that expressly and directly conflicts with a decision of another district court of appeal or of the supreme court on the same question of law. ${ }^{46}$ 
Based on the highlighted language, the issuance of a PCA effectively eliminates the jurisdiction of the Florida Supreme Court to hear the case, even if the outcome of the case would differ among the DCAs. This is troubling, to say the least, as it allows the District Courts to control the jurisdiction of the Supreme Court.

For example, imagine a situation where there are binding precedents in conflict within the five DCAs. This would typically be a good situation for the Florida Supreme Court to take jurisdiction and resolve the conflict. The present PCA practice could frustrate Florida Supreme Court jurisdiction, however, as the District Courts might issue PCAs in each case based on the preexisting precedents in their Districts.

Likewise, consider the issue of workers' compensation appeals, which was a subject raised repeatedly in the Subcommittee. As the First District is the only DCA that hears workers compensation cases,${ }^{47}$ the use of PCAs may effectively prevent an issue from ever being considered by the Florida Supreme Court. The first time a specific workers'-compensation-related issue is decided by the First District may be the only opportunity for the Supreme Court to take the matter up. After the matter is decided, all subsequent cases raising that issue may be decided by PCA, which will effectively eliminate any possibility for the matter to be brought to the Florida Supreme Court as there would be no further opportunity for conflict or another basis under which the Supreme Court could review the matter. This would effectively end development of the law in that particular area unless the First District considers the matter en banc.

\section{iv. Open Government}

Florida is well-known for its broad government in the sunshine laws encoded in Chapter 286 (open meetings) and Chapter 119 (public records) of the Florida Statutes. In situations where a collegial body in Florida meets to conduct public business (be it a municipality, county, special district, Governor and Cabinet, or state board), even when in a quasijudicial capacity, the meeting must be open to the public and the records produced are available for public inspection except where certain limited exemptions to these laws applies.

The judiciary is obviously not subject to these laws. ${ }^{48}$ Nevertheless, Florida's approach to open government makes it increasingly anomalous

47 See $\S 440.271$, Fla. Stat. (2017) ("Review of any order of a judge of compensation claims entered pursuant to this chapter shall be by appeal to the District Court of Appeal, First District.").

48 OfFice of the AtTorney General, GOVERnMENT-In-The-Sunshine MANuAL, Vol. 39, 10-12, 60-61 (2017 ed.); see also art. 1, §24, Fla. Const.; Fla. R. Jud. Adm. 2.420. 
that courts can act through PCAs. If the judiciary has the privilege to be able to have appellate panels meet together and discuss cases in private, it is consistent with principles of the sunshine laws to ensure that at least any final decisions are made public in full. Otherwise, the concern exists that both the deliberations and the reasoning in support of the outcome remain outside of public review. This can be easily cured by requiring the appellate courts to at least provide a brief analysis or citation with the decision, thereby placing in the public record the basis for the decision.

\section{v. Prudential Reason: Precedent}

Another concern with PCAs is that there are comparatively few precedents affirming decisions in Florida, compared to the amount of affirming decisions issued. For example, the reversal rate in Florida is approximately $10 \%$ to $15 \%$ of all cases. ${ }^{49}$ As mentioned previously, PCRs are not permitted, so every reversal in Florida is accompanied by an opinion. This means that $10 \%$ to $15 \%$ of the total decisions issued by district appellate courts in Florida are reversals with an opinion. It has also been established that $75 \%$ of the decisions are PCAs containing no opinion. This means that the remaining $10 \%$ to $15 \%$ of decisions are affirmances with an opinion, which is approximately equal to the number of reversals with an opinion. There are numerous obvious concerns here.

First, there will be approximately as many published opinions affirming the decision of a lower tribunal as reversing a decision. This will lead to a false equivalency in the case law, whereby case law will appear to provide as many grounds for reversal as affirmance. This will also result in fewer decisions than there should be providing guidance to a trial court as to what should be done, as opposed to what should not be done. As online research applications, such as Westlaw and Lexis, make it easier and easier to quickly locate tens or hundreds of decisions on a given point, the law will be skewed on these issues in favor of reversal more than it should be based on the high affirmance rate.

Second, as a general matter, precedent is very helpful to parties as to how to proceed in litigation. As more precedents are issued, there are more case examples that can be used to predict the outcome of a given case. This additional information makes it more likely that a just settlement will be reached that reflects the relative strengths of the parties on the facts and law. If a review of the case law indicates as many precedents supporting

49 Raymont T. Elligett, Jr. \& Amy S. Farrior, To Appeal or Not to Appeal-That is the Client's Question, FlA. BAR J., April 2007, at 16, https://www.floridabar.org/divcom/jn/jnjournal01.nsf/Author/ 1F6571FBC4089CDE852572AC00549D22. 
reversal as affirmance, this will provide a false understanding of the actual state of the law, including the difficulty of obtaining a reversal.

Third, precedent is also helpful to local governments and other entities where issues frequently recur and where checks and balances are present. A local government will typically see the issue that is on appeal again and again, either in a quasi-judicial capacity as the lower tribunal, or in an executive capacity through law enforcement. It is useful for the local government to have as many precedents as possible to guide the government in how to act, which will ensure that the government acts lawfully. This is one of the principle reasons why I proposed expanding the written opinion rule to allow local governments to obtain guidance on a recurring issue even if the local government has lost this particular case.

\section{Treatment by Other Jurisdictions}

\section{a. Federal}

\section{i. Unpublished Opinions}

In the federal system, circuit courts of appeal issue both published and unpublished opinions. ${ }^{50}$ Both decisions are actually "published," in the sense of being made available to the public, although only the published opinions are placed in the Federal Reporter. The unpublished opinions are placed in the Federal Appendix, or are sometimes only available on Westlaw or Lexis.

The difference between published and unpublished opinions relates to precedential value. A published decision is considered binding within the circuit, and must be followed by future panels under the prior panel rule. ${ }^{51}$ It can also clearly establish law for purposes of qualified immunity. ${ }^{52}$ In contrast, an unpublished decision is not binding within the circuit, and serves as only persuasive authority at most. ${ }^{53}$ It can, therefore, be deviated from by later decisions, whether published or unpublished.

The Eleventh Circuit, which includes Florida, Georgia, and Alabama, within its territorial jurisdiction, issues both published and unpublished

50 Each U.S. Court of Appeal has its own procedural rule and practice related to unpublished opinions. In the Eleventh Circuit, the procedural rule can be found at 11TH CIR. R. 36-2 and associated Internal Operating Procedure 6.

51 See, e.g., Smith v. GTE Corp., 236 F. 3d 1292, 1301-03 (11th Cir. 2001) (discussing the importance of the prior panel rule in providing "stability and predictability" in the law).

52 See, e.g., Amnesty Int'l v. Battle, 559 F. 3d 1170 (11th Cir. 2009) ("In this Circuit, only the caselaw of the Supreme Court, the Eleventh Circuit or the law of the highest court of the state where the events took place - in this case, Florida - can 'clearly establish' constitutional rights.").

53 See, e.g., Hogan v. Carter, 85 F. 3d 1113, 1117 (4th Cir. 1996). 
opinions, although unpublished opinions are issued much more frequently. ${ }^{54}$ This allows the Eleventh Circuit to focus time and effort on its published opinions, while still providing an explanation to parties receiving an unpublished opinion.

An appellate rule change allowing for unpublished opinions should be considered as well. To the extent district appellate courts are concerned about writing short explanations that could then become binding precedent with unintended consequences, allowing issuance of short unpublished opinions may solve this problem. ${ }^{55}$

\section{ii. Written Opinions at Trial Court Level}

Another factor that should not be overlooked is that federal district court opinions are often published in the Federal Supplement, Federal Rules of Decision, or directly on Westlaw or Lexis. Indeed, in handling approximately fifty federal civil rights cases while an attorney for MiamiDade County, it was my experience that district judges would resolve virtually every dispositive motion with an opinion and order explaining the basis for granting or denying the motion.

In contrast, my experience in state court was that trial judges were more likely to rule on a dispositive motion through simply granting or denying the motion without explanation. State court trial judges have a much higher case load than their federal counterparts, so this is understandable. The high rate of PCAs causes much more of an issue in state court than it would in federal court. In federal court, a PCA would almost certainly be affirming an already existing written opinion. In contrast, in state court, there is a much higher likelihood of having a case where a legal basis for dismissal or summary judgment is raised, and where that legal basis is rejected without explanation in the denial of a motion, and then later not discussed in a PCA.

54 A review of the published and unpublished opinion logs of the Eleventh Circuit indicate that published opinions are issued much less frequently. The logs are available on the Eleventh Circuit's website at the following links: Published Opinions $\log$, U.S. CT. ApP. ElEVENTH CIR., http://www.ca11.uscourts.gov/published-opinions-log (last visited Mar. 29, 2017); Unpublished Opinions Log, U.S. CT. APP. ELEVENTH CIR., http://www.ca11.uscourts.gov/unpublished-opinions-log (last visited Mar. 29, 2017).

55 The JMC Report mentions the possibility of unpublished opinions but determines they were beyond the purview of its assignment, so the JMC made no recommendation on them. See COMMITTEE ON PER CURIAM AFFIRMED DECISIONS, supra note 1, at 37. 


\section{b. States}

\section{i. JMC Report}

As part of its process, the Judicial Management Council sought information from the ten largest states in population at that time other than Florida regarding their uses of PCAs. ${ }^{56}$ The JMC received responses from nine states: California, Georgia, Illinois, Michigan, New Jersey, New York, Ohio, Pennsylvania, Virginia, and Texas. ${ }^{57}$ Interestingly, three of the largest states, California, New York, and Texas, indicated that their intermediate appellate courts did not use PCAs at all. ${ }^{58}$ The only state that indicated it had a similar amount of reliance on PCAs to Florida was Illinois, which indicated that $89 \%$ of its decisions were by summary orders. ${ }^{59}$

\section{ii. Additional States}

Notably, there is no criteria provided in the Florida Rules of Appellate Procedure for when a PCA should be issued. Indeed, the only criteria provided is for when a written opinion is requested following a PCA. Other states have addressed this issue differently, even providing guidelines for when a PCA can be issued.

For example, the Supreme Court of Appeals of West Virginia recently adopted a rule of procedure permitting memorandum decisions that is a model to be considered. The rule states as follows:

Affirmance. A memorandum decision affirming the decision of the lower tribunal may be entered under this Rule when: (1) this Court finds no substantial question of law and the Court does not disagree with the decision of the lower tribunal as to the question of law; (2) upon consideration of the applicable standard of review and the record presented, this Court finds no prejudicial error; or (3) other just cause exists for summary affirmance. The memorandum decision shall contain a concise statement of the reason for affirmance, and a concise statement of the reason for issuing a memorandum decision instead of an opinion. ${ }^{60}$

\footnotetext{
56 See Committee On Per Curiam Affirmed DeCisions, supra note 1, at 103.

$57 \quad I d$.

$58 \quad I d$.

$59 \quad I d$.

60 W. Va. R. App. P. 21 (emphasis added); see State v. McKinley, 764 S.E. 2d 303, 311 (W. Va.
} 
Likewise, under the Georgia Rules of Appellate Procedure, there are specific criteria for when a PCA can be issued: "(1) the evidence supports the judgment; (2) no reversible error of law appears and an opinion would have no precedential value; (3) the judgment of the court below adequately explains the decision; and/or (4) the issues are controlled adversely to the appellant for the reasons and authority given in the appellee's brief may be affirmed without opinion."

One last example, the New Jersey Rules Governing Appellate Practice permit affirmances without opinion when the Appellate Division determines that any one or more of the following circumstances exists and is dispositive of a matter submitted to the court for decision: "(A) that a judgment of a trial court is based on findings of fact which are adequately supported by evidence; (B) that the evidence in support of a jury verdict is not insufficient; $(\mathrm{C})$ that the determination of a trial court on a motion for a new trial does not constitute a manifest denial of justice; (D) that the decision of an administrative agency is supported by sufficient credible evidence on the record as a whole; and/or (E) that some or all of the arguments made are without sufficient merit to warrant discussion in a written opinion." 62

\section{Recommendation and Conclusion}

\section{a. Limitation of PCAs to Frivolous Appeals}

My first recommendation is for the DCAs (or potentially the Florida Supreme Court through the rulemaking process) to eliminate PCAs entirely or, at the very least, to limit PCAs to cases where the appeal is frivolous. Similarly, in situations where the outcome for the primary issue on appeal is governed squarely by an already decided binding precedent, at least a citation to that case would be provided.

A frivolous appeal, by definition, is one where there is no good faith basis under the facts presented and the state of the law to file an appeal. ${ }^{63}$ Typically, this only occurs if there is already established binding precedent that dictates the result, and there is no good faith basis provided to distinguish or overturn the binding precedent. Likewise, in a case where there is an already established binding precedent, and the appellant seeks to distinguish or overturn it in good faith, but unsuccessfully, the Court may decide that analysis is not needed and that the previously decided precedent

2014).

61 Ga. R. App. P. 36.

62 N.J. R. App. P. 2:11-3.

$63 \S 57.105$, Fla. Stat.; Fla. R. App. P. 9.410. 
speaks for itself.

In these two circumstances, there is less need for analysis, as the appeal should either not have been brought or has been decided based on existing clearly established law. Based on the JMC report, as well as the minutes of the PCA Subcommittee, there will likely be many PCAs or citation PCAs still issued under this standard, particularly in collateral attacks by pro se criminal defendants of criminal court decisions. It will now be clear though that if a PCA is issued, it is because there is no need for any analysis to resolve the case.

\section{b. Brief Explanation in Other Cases that Would Presently be PCAs}

All other PCAs should receive a brief explanation describing why a particular decision was reached. The explanation could address the lead argument on appeal, or could explain why the record was insufficient to reverse, or could even incorporate by reference the decision of the lower tribunal. The opinion could also cite to cases that were the basis for the court's decision to affirm, similar to a citation PCA.

Because of the prevalence of PCAs, a concern exists that the judicial branch would need additional judges or staff if PCAs were eliminated. This is not an idea that should be immediately rejected. If the judiciary were to agree by rule change to write opinions in a substantially greater amount more cases, there would be grounds for an argument to increase the amount of judicial officers. In addition, as many of the decisions replacing PCAs would be brief, it would be possible to consider the use of staff attorneys to prepare short explanations that could then be provided to the panel for approval. These opinions could be issued per curiam as they are today, but they would be per curiam opinions as opposed to PCAs without explanation.

\section{c. Provision of Written Opinion Where Recurring Legal Issue or Where Beneficial to Local Tribunal}

Finally, the proposed expansion to the written opinion rule is an excellent first step in addressing the concerns raised regarding PCAs. The new proposed rule provides two new categories of decisions where a party can request a written opinion following a PCA, in addition to the present category where a written opinion would provide a basis for Supreme Court review (i.e., through conflict jurisdiction). These new categories are (i) where there has been an apparent deviation from established precedent; and (ii) where the decision would provide guidance to the lower tribunal in several circumstances, including where the matter is one of first impression 
or a recurring matter. ${ }^{64}$

The proposed rule change also removes the requirement that the attorney provide a certification of the basis for the motion, which appeared to the subcommittee to indicate that a motion for written opinion was disfavored. Indeed, the proposed rule change includes a comment indicating the intent that the amendment is intended to encourage the granting of more motions for written opinion.

Such an intent is understandable, as it appeared to the Subcommittee based on its review that motions for written opinion were granted extraordinarily rarely, and for far less than $1 \%$ of all PCAs issued. ${ }^{65}$ The proposed amendments will make it much easier to establish grounds for seeking a written opinion and should lead to more being granted. At the very least, this will be an opportunity to determine whether an expanded motion for written opinion provides an adequate remedy for situations where a PCA is improvidently granted, as contemplated by the Judicial Management Council fifteen years ago.

\section{d. Proposal to Constitution Revision Commission}

I also recently proposed a constitutional amendment to the Constitution Revision Commission that would eliminate PCAs by requiring an explanation for all appellate decisions in Florida. The proposed amendment adds the following sentence after the second sentence in Article V, Section 1 of the Florida Constitution relating to Courts: "All appellate decisions must include an explanation of the basis for the decision." This simple statement in the Florida Constitution would make a tremendous impact, as it would lead to substantially more guidance as to why decisions were reached, protect the jurisdiction of the Florida Supreme Court to review conflicts among the DCAs, and ensure that parties know the reasons why they won or lost a particular case.

\section{CONCLUSION}

The prevalence of the PCA in Florida is unique in the United States and is a ground for significant concern based on principles of stare decisis and judicial restraint. The exercise of judicial power receives legitimacy from citation to precedent or an explanation as to why the law requires a certain outcome. By definition, the PCA is outcome determinative, as only an outcome is provided, which does not provide the legal explanation that

64 See Subcommittee on PER CuRiAm AfFiRMEd DeCisions (June 26, 2015), supra note 2.

65 SubCOMmittee ON PER CURIUM AfFirmanCES (Jan. 23, 2015), supra note 13. 
clothes a judicial decision in the law. The Florida Supreme Court should strongly consider limiting PCAs or, at the very least, broadening the ability to seek a written opinion following a PCA. Likewise, the Constitution Revision Commission should consider requiring a written explanation with every appellate decision. There are times when only a reasoned explanation is the just result, regardless of the outcome. 


\section{FLORIDA District COURTS OF APPEALS TABLES}

$\underline{\text { Table 1. Per Curiam Affirmed Decisions v. Written Opinions }}$

February 2016

\begin{tabular}{|l|l|l|l|l|}
\hline District & PCAs & $\begin{array}{l}\text { Written } \\
\text { Opinions }\end{array}$ & $\begin{array}{l}\text { Total } \\
\text { Opinions }\end{array}$ & $\begin{array}{l}\text { Percentage } \\
\text { PCAs/Total }\end{array}$ \\
\hline First DCA & 291 & 67 & 358 & 81.28 \\
\hline Second DCA & 300 & 53 & 353 & 84.98 \\
\hline Third DCA & 110 & 37 & 147 & 74.83 \\
\hline Fourth DCA & 217 & 56 & 273 & 79.49 \\
\hline Fifth DCA & 245 & 71 & 316 & 77.53 \\
\hline
\end{tabular}

\section{March 2016}

\begin{tabular}{|l|l|l|l|l|}
\hline District & PCAs & $\begin{array}{l}\text { Written } \\
\text { Opinions }\end{array}$ & $\begin{array}{l}\text { Total } \\
\text { Opinions }\end{array}$ & $\begin{array}{l}\text { Percentage } \\
\text { PCAs/Total }\end{array}$ \\
\hline First DCA & 184 & 65 & 249 & 73.90 \\
\hline Second DCA & 312 & 58 & 370 & 84.32 \\
\hline Third DCA & 115 & 71 & 186 & 61.83 \\
\hline Fourth DCA & 204 & 92 & 296 & 68.92 \\
\hline Fifth DCA & 125 & 69 & 194 & 64.43 \\
\hline
\end{tabular}

\section{April 2016}

\begin{tabular}{|l|l|l|l|l|}
\hline District & PCAs & $\begin{array}{l}\text { Written } \\
\text { Opinions }\end{array}$ & $\begin{array}{l}\text { Total } \\
\text { Opinions }\end{array}$ & $\begin{array}{l}\text { Percentage } \\
\text { PCAs/Total }\end{array}$ \\
\hline First DCA & 201 & 75 & 276 & 72.83 \\
\hline Second DCA & 271 & 42 & 313 & 86.58 \\
\hline Third DCA & 88 & 42 & 130 & 67.69 \\
\hline Fourth DCA & 208 & 62 & 270 & 77.04 \\
\hline Fifth DCA & 149 & 40 & 189 & 78.84 \\
\hline
\end{tabular}


May 2016

\begin{tabular}{|l|l|l|l|l|}
\hline District & PCAs & $\begin{array}{l}\text { Written } \\
\text { Opinions }\end{array}$ & $\begin{array}{l}\text { Total } \\
\text { Opinions }\end{array}$ & $\begin{array}{l}\text { Percentage } \\
\text { PCAs/Total }\end{array}$ \\
\hline First DCA & 184 & 65 & 249 & 73.89 \\
\hline Second DCA & 279 & 30 & 309 & 90.29 \\
\hline Third DCA & 96 & 53 & 149 & 64.43 \\
\hline Fourth DCA & 186 & 94 & 280 & 66.43 \\
\hline Fifth DCA & 225 & 61 & 286 & 78.67 \\
\hline
\end{tabular}

June 2016

\begin{tabular}{|l|l|l|l|l|}
\hline District & PCAs & $\begin{array}{l}\text { Written } \\
\text { Opinions }\end{array}$ & $\begin{array}{l}\text { Total } \\
\text { Opinions }\end{array}$ & $\begin{array}{l}\text { Percentage } \\
\text { PCAs/Total }\end{array}$ \\
\hline First DCA & 284 & 78 & 362 & 78.45 \\
\hline Second DCA & 240 & 63 & 303 & 79.21 \\
\hline Third DCA & 101 & 46 & 147 & 68.71 \\
\hline Fourth DCA & 225 & 103 & 328 & 68.59 \\
\hline Fifth DCA & 168 & 60 & 228 & 73.68 \\
\hline
\end{tabular}

July 2016

\begin{tabular}{|l|l|l|l|l|}
\hline District & PCAs & $\begin{array}{l}\text { Written } \\
\text { Opinions }\end{array}$ & $\begin{array}{l}\text { Total } \\
\text { Opinions }\end{array}$ & $\begin{array}{l}\text { Percentage } \\
\text { PCAs/Total }\end{array}$ \\
\hline First DCA & 190 & 67 & 257 & 73.93 \\
\hline Second DCA & 174 & 37 & 211 & 82.46 \\
\hline Third DCA & 97 & 53 & 150 & 64.67 \\
\hline Fourth DCA & 135 & 58 & 193 & 69.95 \\
\hline Fifth DCA & 168 & 48 & 216 & 77.78 \\
\hline
\end{tabular}




\section{Table 2. Average by District}

First DCA Average-75.71

\begin{tabular}{|l|l|}
\hline Month & $\begin{array}{l}\text { Percentage } \\
\text { PCAs/Total }\end{array}$ \\
\hline February & $\mathbf{8 1 . 2 8}$ \\
\hline March & $\mathbf{7 3 . 9 0}$ \\
\hline April & $\mathbf{7 2 . 8 3}$ \\
\hline May & $\mathbf{7 3 . 8 9}$ \\
\hline June & $\mathbf{7 8 . 4 5}$ \\
\hline July & $\mathbf{7 3 . 9 3}$ \\
\hline Average & $\mathbf{7 5 . 7 1}$ \\
\hline
\end{tabular}

Second DCA Average-84.64

\begin{tabular}{|l|l|}
\hline Month & $\begin{array}{l}\text { Percentage } \\
\text { PCAs/Total }\end{array}$ \\
\hline February & $\mathbf{8 4 . 9 8}$ \\
\hline March & $\mathbf{8 4 . 3 2}$ \\
\hline April & $\mathbf{8 6 . 5 8}$ \\
\hline May & $\mathbf{9 0 . 2 9}$ \\
\hline June & $\mathbf{7 9 . 2 1}$ \\
\hline July & $\mathbf{8 2 . 4 6}$ \\
\hline Average & $\mathbf{8 4 . 6 4}$ \\
\hline
\end{tabular}

Third DCA Average-67.03
\begin{tabular}{|l|l|}
\hline Month & $\begin{array}{l}\text { Percentage } \\
\text { PCAs/Total }\end{array}$ \\
\hline February & $\mathbf{7 4 . 8 3}$ \\
\hline March & $\mathbf{6 1 . 8 3}$ \\
\hline April & $\mathbf{6 7 . 6 9}$ \\
\hline May & $\mathbf{6 4 . 4 3}$ \\
\hline June & $\mathbf{6 8 . 7 1}$ \\
\hline July & $\mathbf{6 4 . 6 7}$ \\
\hline Average & $\mathbf{6 7 . 0 3}$ \\
\hline
\end{tabular}

Fourth DCA Average-71.74

\begin{tabular}{|l|l|}
\hline Month & $\begin{array}{l}\text { Percentage } \\
\text { PCAs/Total }\end{array}$ \\
\hline February & $\mathbf{7 9 . 4 9}$ \\
\hline March & $\mathbf{6 8 . 9 2}$ \\
\hline April & $\mathbf{7 7 . 0 4}$ \\
\hline May & $\mathbf{6 6 . 4 3}$ \\
\hline June & $\mathbf{6 8 . 5 9}$ \\
\hline July & $\mathbf{6 9 . 9 5}$ \\
\hline Average & $\mathbf{7 1 . 7 4}$ \\
\hline
\end{tabular}

Fifth DCA Average-75.15

\begin{tabular}{|l|l|}
\hline Month & $\begin{array}{l}\text { Percentage } \\
\text { PCAs/Total }\end{array}$ \\
\hline February & $\mathbf{7 7 . 5 3}$ \\
\hline March & $\mathbf{6 4 . 4 3}$ \\
\hline April & $\mathbf{7 8 . 8 4}$ \\
\hline May & $\mathbf{7 8 . 6 7}$ \\
\hline June & $\mathbf{7 3 . 6 8}$ \\
\hline July & $\mathbf{7 7 . 7 8}$ \\
\hline Average & $\mathbf{7 5 . 1 5}$ \\
\hline
\end{tabular}


Table 3. Average for State of Florida

District Court of Appeals for the State of Florida Average-74.85

\begin{tabular}{|l|l|}
\hline District & Percentage \\
\hline First DCA & $\mathbf{7 5 . 7 1}$ \\
\hline Second DCA & $\mathbf{8 4 . 6 4}$ \\
\hline Third DCA & $\mathbf{6 7 . 0 3}$ \\
\hline Fourth DCA & $\mathbf{7 1 . 7 4}$ \\
\hline Fifth DCA & $\mathbf{7 5 . 1 5}$ \\
\hline Average & $\mathbf{7 4 . 8 5}$ \\
\hline
\end{tabular}

